UDC 821.161.2+111.11

DOI https://doi.org/10.32838/2663-6069/2020.2-3/29

Virych $\boldsymbol{O}$. $\boldsymbol{V}$.

South Ukrainian National Pedagogical University named after K. D. Ushynsky

Virych $N$. .

South Ukrainian National Pedagogical University named after K. D. Ushynsky

\title{
MAN IN THE ARTISTIC WORLD OF M. MATIOS
}

The article is devoted to the study of the peculiarities of human existence in the works of M. Matios. The author claims that the philosophical principles of existentialism as a doctrine of man in existence, relations with the world and with himself in his creative or destructive potentials and manifestations allow deep penetration into the artistic chronotope of a literary work, understanding of its emotional meanings and author's intentions.

It is emphasized that the existential state of solitude of each female protagonist is explained by different, often completely opposite existentials, generated by the originality of the characters, formed by different environments, different living conditions and different mental composition of the characters. The writer's means of character formation and coverage of female protagonists' existential manifestations and reactions are extremely diverse, but also always adequate to the individual characteristics of each of them. Reflections of "sweet" Darusia, given the impossibility of their verbal expression, are transmitted through the author's language, which, however, in these cases is almost completely adequate to the internal language of the heroine. The writer uses the same technique, illuminating the inner world of Severyna. The inner monologues of the protagonist herself are short and fragmentary, though capacious and deep in their nature. Instead, the existence of the female protagonist in the "Diary of the Executed" in her most secret movements and reactions is revealed through self-reflection, translated into a written confession, which reveals all the nuances of the inner (not always attractive) world of the heroines.

It was found that the skillful depiction of situations and characters in the studied works and the polyphony of means and methods of their description reveal the depths of different states of the female protagonists' existing consciousness, and thus contribute to finding the existential meanings embedded by the author in the texts and manifested in certain modifications of the inner problems of human existence, among which the most significant is the problem of worldview and personal choice, which is the basis of the presence or absence of sense in human existence.

Key words: artistic objectivity, being, existential state, choice, existence.

Problem statement. The most important thing for a person today and always is determination of their place in life, search for the truth, the desire to overcome feelings of discomfort, i. e. uncertainty, loneliness, misunderstanding, filling the emptiness with something important, because every existence is unique and inimitable. Although human existence is subject to general structuring (such as being in the world, being with others), these general structures are immersed in a specific situation, as a result of which human existence becomes unique.

Each epoch, each period of historical existence poses new problems to humanity, outlines its range of philosophical, socio-political, moral and ethical tasks.

But whatever the challenges of the time are, the problem of man has always remained relevant in its relationship with the epoch and eternity, in its role as a subject and an object of chronos, which itself provokes its challenges and responds to them with its own actions, suffering, and sometimes life.

That is why the philosophy of existentialism, which based its thinking on human existence "here and now", became the leading philosophical current in the unstable twentieth century and in various modifications and interpretations has remained so today, passing from the postulate of concentration as the basis of self- and God-knowledge in the teachings of Blessed Augustine, through the "fear and trembling" of S. Kierkegaard and the tragedy of the abandonment of man in the world of K. Jaspers, M. Heidegger et al., through the idea of rebellion and Prometheanism of French existentialists to flashes of light in works of N. Abbaniano and O. Bolnov.

Today no one will be surprised at the statement that the existential type of philosophizing was inherent in 
Ukrainian thinkers of the princely era (for example, the Teachings of Prince Volodymyr Monomakh to his children), its bright manifestation can be found in the Baroque era, especially in the works of H. Skovoroda, it was natural for T. Shevchenko, Lesia Ukrainka, I. Franko, for the writers of the Executed Renaissance: V. Domontovych, V. Pidmohylnyi, H. Kosynka, V. Vynnychenko, it was in the focus of works by S. Pavlychko, V. Aheieva, N. Mykhailovska, L. Vodiana and a number of other researchers.

In this regard, we would like to emphasize that the existential way of philosophizing in the works of our Ukrainian thinkers and writers differed from the European philosophizing of the first half of the twentieth century by the presence of an optimistic component, existentials of rejoicing, joy, love of life.

The optimistic component is an essential feature of philosophical thinking of modern Ukrainian scientists, in particular representatives of the Kyiv Existential and Anthropological School - a bright center of studying "man and human existence in its personal identity" [6, p. 12].

It is obvious that any philosophical concepts arise as responses to the challenges of time, which are first perceived and recorded by literature, by virtue of the very mental organization of a true artist, which can serve as a barometer of social needs, thoughts and attitudes, which gives the right to consider literature as a form of philosophy.

Philosophical principles of existentialism as a doctrine of man in existence, relations with the world and with himself in their creative or destructive potentials and manifestations allow deep penetration into the artistic chronotope of a literary work, understanding of its emotional meanings and author's intentions.

Of particular importance are studies of existential issues of works that have an impact on the formation of the general concept of man, which is a particularly topical issue in the period of total pragmatization of life and the spread of nihilism.

Analysis of recent research. The works of Maria Matios, which have an extremely wide readership, have repeatedly been the subject of observation by researchers. Some problems of the writer's works from the point of view of existential issues were also considered. Such works include O. Lilik's pilot study "Creativity is a continuous dream of human infinity: the existential paradigm of Maria Matios", which analyzes small prose and novels "Almost never the other way around", as well as a number of works by I. Nasminchuk, including the $\mathrm{PhD}$ thesis "Prose of Maria Matios: Peculiarities of Individual Style" and an interesting study "The Existence of a Woman in the Prose of Maria Matios: A Feminocentric Approach", where, among other things, attention is paid to the female protagonist of "Diary of the Executed".

Setting the task. The aim of the article is to study the existential of solitude in the works of M. Matios ("Sweet Darussia", "Moskalytsia", "Diary of the Executed").

Realization of the aim implies the solution of the following tasks: 1) comprehension of the writer's works from the point of view of philosophy of existentialism; 2) ways of artistic realization of existential issues.

Main body. For analysis, three works are selected from the significant creative achievements of the writer, the females characters of which are completely single women, for one reason or another internally alienated from society, with destinies, broken either by external forces or other factors. These are the works "Sweet Darusia", "Moskalytsia" and "Diary of the Executed", the female characters of which experience a boundary situation that encourages conscious personal choice. Thus, already at the conceptual level we face the notions that are dominant in the philosophy of existentialism: loneliness, alienation, boundary situations, self-reflection, choice, and so on.

These semantic concepts are not declared by the author, but are realized in the "artistic world" [1] by means of poetics in their systemic, mutually agreed relations [1, p. 5], including the subject environment of the female characters, and their actions and reactions to the world, and internal monologues, and dialogues, and symbolic or mythopoetic content of specific phenomena of the characters.

For example, the reader's first meeting with the female character of the novel "Sweet Darusia" allows us to feel the gap between her inner world and the world of people among whom she lives.

The marker of alienation is the attitude to asters unsumptious and unpretentious flowers, which neighbour Vasiuta weeds out of the garden and throws away as unnecessary. And Darusia at this time "is sitting in the flower garden between the asters, three steps from Maria and Vasilina <..> stroking the cheerful heads of asters, curling fragrant curls with her palm, speaking to them, telling what she wants, laughing" $[3$, p. 5].

The subject environment of sweet Darusia is the world of nature. The author does not describe the interior of her home, household items, which is fixed by the reader's consciousness as a fact of the heroines' disconnection from the world of things, from domestic interests. 
The subject line of Darusia's world is connected with the natural environment. This is the land where a woman buries herself to gain strength, the water that takes away the pain from her exhausted body, the old half-dried pear, which Darusia herself "saves" from sadness and loneliness, cleaning with ribbons and braces, because "why should a tree be sad when the sun warms up, when Darusia doesn't feel pain in her brain... can't a pear have a shirt embroidered by Darusia's hands today?" [3, p. 5].

The subject-domestic environment of the female protagonist of the story "Moskalytsia" is also not marked by diversity. In addition to the clock, secretly taken from the looted home of their good ruined and taken away owners, the ticking of which "always gave her balance and peace... As if confirming the immutability of human endurance" [4, p. 16-17], a basket with vipers and a cauldron in which they cook medicinal herbs, there are, in fact, no useful things around Severina, which also contributes to the understanding of the instability and disorder of Severina's existence.

Thus, not only subjectivity per se has in the inner world of the works of M. Matios semantic and content load. The absence of a certain number of objects and the author's removal of a certain category of things from the artistic reality she creates are also artistically functional.

Instead, like in "Sweet Darusia", the subject matter included in the artistic reality of the story "Moskalytsia" is again elements of wildlife: the rock to which the fragile house of Severina leaned, the forest, the "skinny" path "repeating the zigzags of local people's lives" [4, p. 18], which breaks above the stream, the stream itself, which at the time of the flood resembles human passions, "as ruthlessly shred mountains and destinies, as only people can shred each other" [4, p. 25], and even mountain ranges, reminding Severina of broken human destinies.

All these components of landscape subjectivity, like in "Sweet Darusia", are endowed with a high degree of intentionality, especially when in some cases the writer herself suggests reading of the significance of a component.

Repeated several times image of Severina's stable, which "has grown into a steep hill overgrown with thick beech forest", becomes an informant not only about the dwelling itself, which is actually uninhabitable, but also about the heroine herself - an inconspicuous, gentle speck in the winds of history, which, however, does not fall, but stands firmly on the rocking earth, having its support, its "rock", which is, as convincingly shown in the story, its mind, its inner moral law.
Equally significant are the animals that surround the female characters of both works: in "Sweet Darusia" - dogs that accompany a woman in her solemn walks to "outside Yorchikha"; in "Moskalytsia" cats and vipers. All these animals in mythological semantics have a great semiotic content and also greatly contribute to the expansion and deepening of the interpretive possibilities of texts.

Thus, the realities included by the writer in the artistic reality of the works, create a kind of semiotic system that helps to penetrate deeper into the inner world of the characters, to understand the specifics of their worldview and outlook, their existence.

No less informative is the artistic subjectivity in the work "Diary of the Executed", the genre of which the writer determined as "psychological pilot study".

The dominants of the subject line of the world in which Larysa Kovalchuk operates are a bedroom, a bed, the expanse of which (like an airfield!) is emphasized several times, linen, sheets, a mirror, which are also codes of the character's life, clearly characterizing her interests and feelings.

Thus, the very selection of the depicted realia of artistic reality, in which the female characters of the considered works of M. Matios function, as well as the objectivity with which this reality is filled, are artistically functional in the works. They contribute not only to a deeper penetration into the inner world of the heroines, but also to the awareness of the main problem of the works, which is the existential problem of solitude, alienation of man from society.

Another existential problem presented in the works of M. Matios is the problem of crisis states, which often lead to loneliness and become the initial stage of existence - understanding of being and oneself in being, which encourages the choice of values.

Severina-Moskalytsia was immersed in such a state of crisis by the very fact of her birth (a bystrychka born to an orphan raped in the First World War by "rusak"), but Sweet Darusia was born into a family where tender love and deep respect between parents prevailed, she was beloved child, brought up on the principles of high morality and truth.

And yet, the fate of both women, equally distant from political and social problems - all that has to do with historical shifts - was ruthlessly driven by the "chariot of history", putting them on the brink of life and death; they both became innocent victims of the absurdity of the world, sharing the fate of their folk.

The use of the term boundary (borderline, crisis) situation, we think, requires clarification. Very often, even in some scientific works, it is used to define 
the state of man in his confrontation with death, suffering, catastrophe, that is, with what is a danger to his current existence. However, K. Jaspers, who introduced this term to philosophical use, did not consider the very fact of threat to human existence as a boundary situation. He called such a situation only when a person in crisis realizes the catastrophic nature of his condition, comprehends it, "when through the factuality (empiricality) of being existence sprouts, i. e. shoots of human self-understanding and self-awareness, which are the basis of personality in their future choice and self-realization" [8, p. 151-153].

It is this existential sense in which the term boundary situation will be used further. The term crisis state or crisis conditions will be used to describe a state when a person is in crisis with the world, because, following Jaspers, we do not interpret this situational boundary as a boundary between relative well-being and unhappiness, and not even as a boundary between life and death, but as a boundary between the pre-existential state and human existence, i. e. awareness and comprehension of one's own being and oneself in being.

Thus, an existential person can be considered a person who has realized his otherness and his rejection of the absurd world, who comprehends the world around him and himself in the world, determining his own values, making a choice, and building his life according to this choice.

Do the female protagonists of the considered works by M. Matios meet these criteria, or in other words, is it legitimate to consider their existence as existence?

Obviously, yes. Each of them experienced a state of crisis - a situation that threatened their physical existence. For Darusia, this situation was her innocent "sin of innocence" (betrayal of the parents' secret, for which the child was cursed by the mother; mother's suicide; mental shock, which led to the loss of voice, and thus led to external loneliness) $[7$, p. 8$]$ of the child due to the impossibility of her verbal communication with the environment, and due to the environment's perception of her as mentally ill.

For Severina ("Moskalytsia") the state of crisis that led to her alienation from the world around her, that is, her external loneliness, first in mental and then in its physical form, was, as already noted, her very birth. For Larysa Kovalchuk ("Diary of the Executed"), such a crisis is a despair at the inability to satisfy the sexual attraction to her beloved and a suicide attempt. For her, this crisis threshold became a boundary situation between pre-existential and existential existence, although we see elements of existential consciousness in her youth, as evidenced by her diary entries about letters from guys in the army, the lack of interest in life, etc. [5].

For the heroine of the novel "Moskalytsia" a bondary situation that leads Severina to the realization of her fundamental alienation from the world and the conscious choice of loneliness as solitude [7, p. 16], was the arrest and deportation to Siberia of her good guardians and masters Onufriichuk, a clash with the senseless and cruel force of the ruling world.

The process of sweet Darusia's going beyond the ordinary into the sphere of the extreme existence is not described in the novel.

We meet the heroine as a person with an existing consciousness, a person who in her own way is naive and childish, but critically comprehends herself and the surrounding world.

Putting his characters in the same existential situation, which in the philosophical literature is defined as solitude, i. e. "voluntary promotion of oneself into loneliness" [7, p. 16], M. Matios skillfully depicts their completely different reactions to this situation, to the world and to themselves, thus emphasizing one of the main theses of the philosophy of existentialism about the uniqueness of each individual and the uniqueness of each personal being.

Analyzing the existential state of solitude of the female characters in the three works of M. Matios, we must pay attention to the fact that in each case this state is saturated not only with different existentials, different dynamics of their detection or combinations, but also has a very different emotional and ethical basis and different direction, which obviously requires a certain classification of states of solitude.

Conclusions. Thus, although researchers do not consider M. Matios's prose as philosophical, and sometimes characterize it as "melodramatic", sentimental, "not for gourmets", its deeper analysis proves that the writer's works are consistent with the basic ideas of modern philosophical scholars, in particular with the ideas of existentialism - the doctrine that puts in the focus of interest a particular person in their particular being.

\section{References:}

1. Клочек Г. «Художній світ» як категоріальне поняття: матеріали до спеціального курсу «Теорія літературного твору як мистецтво його аналізу». Кіровоград : РББ КДПУ, 2007. 24 с. 
2. Кьеркегор С. Страх и трепет. Москва : Республика, 1997. 383 с.

3. Матіос М. Солодка Даруся: драма на три життя. Львів : Піраміда, 2007. 185 с.

4. Матіос М. Москалиця. Львів : Піраміда, 2008. 64 с.

5. Матіос М. Щоденник страченої. Львів : Піраміда, 2005. 192 с.

6. Філософія. Світ людини. Курс лекцій : навчальний посібник / В. Табачковський, М. Булатов, Н. Хамітов та ін. Київ : Либідь, 2003. 432 с.

7. Хамітов Н. Самотність як феномен людського буття : автореф. дис. ... докт. філос. наук : 09.0004 ; Інститут філософії ім. Г. С. Сковороди НАН України. Київ, 1998. 34 с.

8. Ясперс К. Смысл и назначение истории. Москва : Политиздат, 1991. 527 с.

\section{Вірич О. В., Вірич Н. В. ЛЮДИНА В ХУДОЖНЬОМУ СВІТІ М. МАТІОС}

Статтю присвячено дослідженню особливостей людської екзистениії у творах М. Матіос. Зазначено, що філософські засади екзистенціалізму як учення про людину в бутті, стосунках зі світом та із самою собою в ї̈ творчих чи руйнівних потенціях і виявах дають можливість глибоко проникнути в художній хронотоп літературного твору, осмислити його емотивні змісти та авторські інтенції.

Підкреслено, щуо екзистениійний стан усамітнення кожної з героїнь експлікується різними, часто цілком протилежними екзистенціалами, зумовленими своєрідністю характерів, сформованими різним середовищем, різними умовами життя та різним психічним складом героїв. Засоби характеротворення та висвітлення екзистенційних виявів і реакцій героїнь у письменниці надзвичайно різноманітні, проте завжди адекватні індивідуальним особливостям кожної з них. Рефлексії «солодкої» Дарусі, з огляду на неможливість їх вербального самовираження, передаються через авторську мову, яка, однак, у иих випадках майже повністю адекватна внутрішній мові самої героӥні. До такого ж прийому вдається письменниия під час висвітлення внутрішнього світу Северини. Внутрішні монологи самої героӥні скупі й уривчасті, хоча при иььому місткі та глибокі за суттю. Натомість екзистениія героїні «Щоденника страченої» в ї̈ найпотаємніших порухах і реакціях розкривається через саморефрлексію, перелиту в письмову сповідь, у якій розкрито всі нюанси внутрішнього (не завжди привабливого) світу героїнь.

Простежено, що майстерне змалювання ситуачій іхарактеріву досліджуваних творахта поліфонія засобів і прийомів їх зображення розкривають глибини різних станів екзистуючої свідомості героӥнь, а тому сприяють віднайденню екзистенційних сенсів, закладених автором у тексти, щуо виявляються y своєрідних модифікаціях внутрішніх проблем людського існування, найважливішою з-поміж яких постає проблема світосприйняття, світовідношення та особистісного вибору, щуо є основою наявності чи відсутності сенсу людського буття.

Ключові слова: художня предметність, буття, екзистенційний стан, вибір, екзистениія. 